\title{
STAKEHOLDER PERSPECTIVES ON CLIMATE CHANGE EFFECTS ON TOURISM ACTIVITIES IN THE NORTHERN ROMANIAN CARPATHIANS: VATRA DORNEI RESORT CASE STUDY
}

\author{
Ana Irina Dincăa ${ }^{\mathrm{a} *}$, Camelia Surugiu ${ }^{\mathrm{b}}$, Marius Surugiuc ${ }^{\mathrm{c}}$, Cristi Frenţ ${ }^{\mathrm{b}}$ \\ ${ }^{a}$ Department of Human and Economic Geography, Faculty of Geography, University of Bucharest, Romania \\ ${ }^{a}$ National Institute for Tourism Research and Development, Bucharest, Romania \\ ${ }^{c}$ National Institute of Economic Research, Romanian Academy, Bucharest, Romania
}

\begin{abstract}
Less approached by scientific literature, stakeholder perspective on the effects of climate change for tourism activities is a very actual topic. As an essential part of the complex study of climate - tourism relationship, it needs to be investigated and illustrated through study cases. The present paper approaches this original topic for Vatra Dornei complex spa and mountain resort. Located in the northern part of Romanian Carpathians this destination depends to a great extent on climate resources which show a clear variability of main parameters on which its outdoor activities are based. In this context the voice of stakeholders involved in the local tourism industry is of great importance to certify and illustrate previously obtained modelling evidences. The present paper consequently outlines the main results of a survey undertaken on the topic of climate change effects on tourism in Vatra Dornei in the attempt to better characterize this complex interrelationship.
\end{abstract}

Key words: Stakeholder, Survey, Climate Change, Vatra Dornei, Spa, Mountain resort.

Article Info: Manuscript Received: October 20, 2013; Revised: March 25, 2014; Accepted: April 15, 2014 ; Online: May 31, 2014.

\section{Introduction}

The relation between tourism and climate change represents a topic approached by the scientific literature for almost two decades, both recreational activities exposure to changing parameters of the natural factor as well as tourism impact on climate being issues of interest. The research on scenarios and modelling of climate change impact on recreational activities and the design of political declarations with socio-economic implications, of reports (e.g. Stern Review, 2006) and adaptation strategies for different territorial levels fueled lately a whole range of studies, articles and books on this very actual topic. However according to "the Inter-governmental Panel on Climate Change (IPCC) assertion that climate change is now unequivocally taking place“ (Dickinson, 2010) and to the corresponding following recommendations in Davos Declaration (2007) "there is a need to

* Corresponding author:

Address: University of Bucharest, Faculty of Geography, 1, Nicolae Bălcescu Avenue, 010041, Bucharest, Romania.

Telephone: +4 0213153074

Email: dincaanairina@gmail.com urgently adopt a range of policies encouraging real sustainable tourism that reflects environmental, social, economic as well as climate responsiveness" (UNWTO, 2007). Moreover in its following reports UNWTO reinforces the role of climate as "a key resource for tourism which is consequently highly sensitive to the impacts of climate change and global warming" (according to UNWTO, 2007) distinguishing a whole range of different types of impacts resulting from the interaction tourism/climate change (e.g. direct climate impacts, indirect environmental change impacts, impacts of mitigation policies on tourism mobility, indirect societal change impacts (UNWTO, 2009)).

Direct climate impacts are underlined both by scientific studies and policy reports especially for sun and sea (Jennings, 2004; Phillips \& Jones, 2006; Buzinde, Manuel-Navarrete, Kerstetter \& Redclift, 2010; Jones \& Phillips (edits.), 2011; Surugiu, Breda, Surugiu, \& Dincă, 2011; Surugiu, Frenț, Surugiu, \& Dincă, 2012) and winter sports holidays (Koch \& Rudel, 1990; Breiling, 1993a, 1993b, Bultot, Gellens, Spreafisco \& Schedler, 1994; Abegg, 1996; Abegg \& Froesch, 1994; Koenig, 1994; Koening \& Abegg, 1997; Mohnl, 1996; 
Meier, 1998, Beniston, 2003, Breiling \& Charamza, 1999, Burki, 2002, Bürki, Elsasser \& Abegg, 2003; Bürki, Elsasser, Abegg, \& Koenig, 2005, Bigano \& Bosello, 2007, Duchosal, 2007; Moen \& Fredman, 2007; Scott, McBoyle, Mills \& Minogue, 2004; Scott, McBoyle, Minogue \& Mills, 2006; Scott, Jones \& Konopek, 2007; Tepfenhart, Mauser \& Siebel, 2007; Tervo, 2007; Vrtačnik Garbas, 2007; Micu \& Dincă, 2008; Dincă, Surugiu \& Micu, 2009; Surugiu, Dincă \& Micu, 2010; Dingeldey \& Soboll, 2010; Pickering, 2011; Surugiu, Frenţ, Surugiu, \& Dincă, 2012; Dawson \& Scott, 2013), in each case tourism seasons and demand depending clearly on the climate factor. At the same time coastal and mountain areas are also particularly sensitive to environmental changes as a whole. As the socioeconomic and practical needs of tourism industry demanded, more and more studies oriented lately towards different destinations as a whole estimating climate change impact on different types of tourism activities, destinations or regions within a national level (e.g. CLAVIER, 20o8; Sebek, 1990; Hein, Metzger \& Moreno, 2009; Dincă, Surugiu and Micu, 2009; Surugiu, Frenţ, Surugiu, \& Dincă, 2012; Peric, Jurdana \& Grdic, 2013; Ge, Dai, Liu, Zhong \& Liu, 2013).

Recent studies approaching the relation climate change - tourism activities focused also on adaptation possibilities of tourism industry (CLAVIER, 2008). In this regard an essential element was to define stakeholders reaction and point of view on the matter as the key element to design responsible sustainable strategies at the local and regional level in view of this global problem with different local effects (Hoffmann, Sprengel, Ziegler, Kolb \& Abegg, 2009; Frey \& George, 2010; Wong, De Lacy \& Jiang, 2012; Pongkijvorasin \& Chotiyaputta, 2013; Trawoger, 2014, in press). Due to the latest scientific and politic reactions and to late evolving trends regarding tourism climate change relation more and more studies are approaching now the stakeholder attitudes and reactions on the issue. They are considered a key element for adaptation of recreational industry to the now uncontested climate change problem (Bicknell \& McManus 2006; Nicholls \& Holecek, 2008; Turton, Dickson, Hadwen, Jorgensen, Pham, Simmons, Tremblay \& Wilson, 2010; Charara, Cashman, Bonnell \& Gehr, 2011 in Becken, 2013; Trawoger, 2014, in press) as "the key players' awareness of climate change may determine whether effective action is taken" (Belle \& Bramwell, 2005; Klint, Jiang, Law, De Lacy, Filep, Calgaro, Dominey-Howes \& Harrison, 2012 in Trawoger, 2014, in press).

According to these latest approaches our study focuses on the relation climate change - tourism activities from the point of view of the local stakeholders, trying to detach and emphasize maybe the most important voice which might determine on a long term the extent of economic vulnerability (CLAVIER, 2008) to the exposure to this physical parameter, namely climate. If quoting the generous literature which attempts to emphasize the stakeholder's voice as a "qualitative" variable verifying and certifying results revealed by data modeling (CLAVIER, 2008), "the interrelationship between tourism and climate change is far more complex than deterministic models of temperature change and travel patterns" (Scott, Hall \& Gössling, 2012).

In fact the present paper inscribes itself in the latest research trends as mentioned above and is the result of a much broader study which tries to define the relation climate change tourism activities for three different types of tourism destinations in Romania (mountain winter sports resort, littoral spa resort and mountain spa resort). The study tried in a first stage to emphasize the relation climate - tourism activities from the unilateral perspective of both climate trends and tourism patterns. Further on a multivariable perspective was needed and approached through both econometric modeling and a stakeholder survey on the topic. The present paper focuses on this last and maybe most important and complex part of the climate change - tourism activities research, addressing the mountain spa resort of Vatra Dornei, representative for its tourism market profile among other destinations in Romania. As well as tourism activities in general Romanian tourism industry suffers the effects of climate change phenomenon mostly for winter sports and littoral activities. For both tourism destinations in general and Romanian resorts in particular there have been little researches and preoccupations so far to reveal climate variability impact on other types of destinations. However if looking at different types of activities displayed by the tourism offer of spa mountain resorts one should remark their high dependency on natural conditions and consequently on climate as an important recreational resource. In this respect the present paper contains innovative elements and represents an original approach for studies on this topic.

As reflected also by the international context, at the level of main types of Romanian tourism destinations climate change impacts are felt by both Black sea littoral resorts and winter sports mountainous or hilly recreational destinations. Climate resorts and outdoor tourism activities appealing to climate as both an outdoor favourable factor and a cure element represent however a third type of recreational destinations where climate change would clearly have an impact upon the natural resource responsible for tourism attractiveness (Surugiu, Frenţ, Surugiu, \& Dincă, 2012). Even if less obvious in terms of generated tourism behavior response to present climate variability, long term climate change effects upon outdoor recreational activities and spa climate based tourism appear to have the most important economic effects. Generally it is agreed that "climate is a natural tourism resource and it is an element that, thanks to 
human intervention, facilitates tourism and the satisfaction of demand" (Belén Gómez Martín, 2005).

Climate attracts tourists in the case of mountain tourism both in summer and in winter through specific parameters and elements. Consequently climate change would be a complex stressing factor determining the attractiveness of outdoor activities and air therapy in mountain destinations. This is clearly the case of Vatra Dornei resort, the destination which constitutes the object of our study, which depends on climate conditions as both curative factors and as tourists triggering elements for winter sports and summer mountaineering.

\section{Work hypothesis and methods}

The relation tourism / climate change or tourism vulnerability to climate change stress is perceived as a function of exposure and sensitivity of tourist areas to the variability of climate factors, as well as of economic and sector adaptive capacity: Economic Vulnerability $=\mathrm{f}$ (Potential Economic Impacts, Adaptive Capacity) (CLAVIER, 20o8). In order to understand the exposure and the economic sensitivity in depth analysis of past evolution and future trends of climate parameters respectively of socio-economic indicators were made (Surugiu, Frenţ, Surugiu, \& Dincă, 2012).

The connection between climate and tourism variables was discussed in a previous part of a more ample study through the use of multiple regressions and econometric analysis at the level of Vatra Dornei resort, selected as a representative traditional spa and climatic tourism destination of Romania. Located in the north of Eastern Romanian Carpathians, the settlement is a complex destination that reflects the evolving cycle of tourism planning and consumerism for Romania. The resort was developed as a spa recreational location before the First World War, meeting a reinforcement of balneal structures designed for social mass tourism during communism era when also a winter sports domain was planned. At present Vatra Dornei is perceived as a complex destination for spa and winter sports as well as also for green ecotourism and active holidays. The last segment reflects new consumerism era trends in terms of recreation, owing the potential to rediscover and reinvent old spa locations in general and to rejuvenate spa tourism in this location in particular (Butler, 1980; Erdeli, Dincă, Gheorghilaş \& Surugiu, 2011; Dincă, 2013).

Taking into consideration the evolution and the profile of tourism activities in Vatra Dornei resort on the one hand and the complexity of tourism industry and of tourist behavior on the other hand the task of detaching the impact of climate change upon local tourism industry is even more difficult. Consequently a compulsory element in order to reflect tourism vulnerability to climate change appears to be in general and particularly for the present case study the local stakeholder opinion on the issue. Stakeholders are to certify climate change influence if already felt at the level of local tourism industry. At the same time they represent the key variable in contouring further scenarios of possible climate change impact and adaptability of this economic sector to climate change exposure at local level. Moreover stakeholders represent a core element which should be addressed in the local decision making process and for reshaping local development and environmental policies (Kontogianni, Skourtos, Langford, Bateman \& Georgiou, 2001; Reed, 2008).

Therefore our study aims to outline stakeholders' point of view upon the interrelation climate change tourism at the local level of a representative Romanian Carpathians spa tourism resort illustrated by the complex traditional balneal tourism destination of Vatra Dornei. Taking into consideration the input coming from previous statistic and econometric analysis for exposure and sensitivity, stakeholder's voice was essential in order to reflect the adaptive capacity of local industry to the climate change challenge and represents a key issue in the tourism vulnerability equation.

As work method a survey was thus applied to stakeholders representing local tourism industry and to local experts on environmental issues in order to verify previous statistic results and to deepen the research on the topic of climate change effects on tourism activities. A challenge in our research was considered from the first place the small number of local stakeholders to represent our target group and though the limits imposed in their sampling. Nevertheless the suitable solution, as in the case of other studies focusing economic effects caused by environmental phenomena, seemed to be a mixed methodological approach combining the questionnaire survey and the focus group methods (Kontogianni, Skourtos, Langford, Bateman \& Georgiou, 2001).

Two main groups of stakeholders were identified and selected in order to apply the survey, namely representatives of local tourism industry (mainly accommodation units but also tourism agencies or ski tracks, sport and leisure services) and local experts on environment issues coming from research, secondary and superior education local units (e.g.: researchers at Călimani National Park, researchers and tourism experts at CEFIDEC Vatra Dornei - local center for human resource training in mountain economy, experienced teachers and inspectors of geography with environment research activities in the area). Both groups were needed in order to increase the accuracy of survey results meant to determine the present economic vulnerability of the local tourism industry to climate change and to verify previously obtained modeling results. 
A total sample of 45 answers was obtained, among which one third (14 answers) have been obtained from local environmental experts and two thirds (31 answers) from representatives of local tourism industry, as the core focus group of the survey. Questionnaires have been presented and sent to all 41 accommodation units located in Vatra Dornei resort and resent twice in order to obtain a satisfactory response rate. Despite its theoretical limitations and taken into consideration the practical efficacy of the method (Rotariu (coord.), 2006), cluster or group sampling method was chosen and was improved through expert choice sampling technique and through the focus group method perspective. In fact the study followed to obtain answers mainly from the group of stakeholders directly involved in local tourism industry on the one hand and from local experts on environmental problems on the other. In what the first mentioned stakeholder group is concerned after each interview round the sampling was readjusted in order to grand equal chances for different types of accommodation structures to fit in a balanced way within their clusters. The considered balancing criteria were the types of accommodation structures according to their capacity (large hotel units displaying over 100 accommodation places vs. small hotel units and boarding houses) and according to their profile (accommodation units including a spa structure formed a separate cluster in our research).

Therefore if discussing the representativeness of the local industry sample group one should say that various accommodation units have been selected including hotels, motels and boarding houses to be found scattered in different areas of Vatra Dornei resort. The sample thus covered all types of units with different tourism profiles from spa to agritourism and from mass to small capacity units in the attempt to catch all possible voices and opinions of industry stakeholders on the matter. In fact the respondents to our survey were representatives for accommodation units concentrating more than $70 \%$ of the total number of accommodation units and over $50 \%$ of the total capacity in terms of bed places at the local level to which representatives of tourism agencies and tourism services providers were added. The respondents, considered to be representative for their units, were upon the case managers, administrators, chief accountants or chief receptionists of the units.

They were persons with a great experience in the field and working in the interview location for at least 5 years. In fact many of them were locals from Vatra Dornei working for more than 20 years in tourism and some times for more than one decade at their last working place they represented for the survey. In this way the representativeness of stakeholder focus group was insured increasing the credibility of respondents' answers. The survey was applied through direct face to face and phone interviews in the August
- October 2012 period by the project team so as to avoid any error generated by this work phase and to obtain complete and accurate answers for all different subsets of questions that have been asked. In the end a 45 questionnaires sample was obtained, representing the local stakeholder's point of view upon climate change - tourism activities interrelation according to their already felt and possible future effects in Vatra Dornei resort. Its main results are further detailed in the form of shares within this total sample in the next pages of the present paper.

\section{Input statistic and modeling results}

Statistic data for available tourism indicators at local level, analyzed for the $1985-2010$ period, showed an increased internal sensitivity of tourism industry for Vatra Dornei resort which is to be further challenged according to trends in climate data by the environmental climate change external stressor. In terms of tourism patterns the resort displayed lately a rejuvenating tendency by reorienting itself towards new trends of recreational consumerism (Dincă, 2013). In the last years Vatra Dornei witnessed the appearance of new accommodation structures of boardinghouse and villa type, answering the tastes and preferences of the contemporary mass-postmass tourism (Light \& Dumbrăveanu, 1999 in Dincă, 2013) which adopted patterns of nature active holidays with regard to alternative small scale recreational activities. Despite of the recent revival of its tourism market, the resort suffered an obvious decline of tourism arrivals after 1990 (Dincă, 2013).

This is mainly explained by the dependency on an inert and declining social system inherited and maintained for balneal destinations in our country since the socialist epoch (Erdeli, Dincă, Gheorghilaş \& Surugiu, 2011) which declined even more during recent recession years. On the other hand, modernized spa units and treatment structures lost the artificial protection of the above mentioned system and could not fill the demand gap in the context of a tough international and internal market competition. The result for a genuine traditional spa resort was that more and more stakeholders of smaller dimensions oriented rather towards new emerging outdoor recreational activities: mountaineering, active or/and relaxing holidays especially in the summer season and towards winter sport activities in the cold season.

Consequently an increased resort dependency on climate conditions resulted, as the local tourism industry accentuated the importance of air therapy and climate conditions, and thus a higher sensitivity of tourism industry to the climate change factor may be underlined. All these industry evolving trends become even more important in the context of tourism activities exposure to evolving climate and bioclimate 
parameters. Their analysis, through data obtained from Poiana Stampei meteorological station for the 1961 - 2010 period, outlined increasing trends for monthly multiannual temperatures, respectively of the index of thermal comfort ( $\left.{ }^{\circ} \mathrm{TEE}\right)$ calculated on Missenard's formula (Ciangă, 1998; Cheval, 2003).

This is valid especially for peak summer months (June - August) with a rate between 0,3 $0,4^{\circ} \mathrm{C} /$ decade respectively between 0,6 $0,7^{\circ} \mathrm{TEE} /$ decade (the latter especially for the 13 p.m. 19 p.m. daily interval). Trends for both indicators showed important statistic significances (Surugiu, Frenţ, Surugiu, \& Dincă, 2012). At the same time regressions runned in a previous first part of our study have outlined a connection between precipitations and annual temperature increase and the decrease of the occupancy rate in accommodation units (Surugiu, Frenţ, Surugiu, \& Dincă, 2012). The need to consult tourism stakeholders on climate change issue and on its influence upon their activities was more than obvious at this point of our research. On the other hand the opinion of local environmental experts was needed in order to increase the objectivity degree of the overall sample regarding economic exposure to the climate change stress. Consequently, as already stated, at this stage of the study, a complex survey was applied at the level of Vatra Dornei resort aiming to emphasize the climate change - tourism activities interrelation and to determine the adaptation capacity of local industry to the evolving climate conditions, verifying at the same time previous statistic and modelling results as explained above.

\section{Stakeholders' opinion on climate change impact on tourism in Vatra Dornei resort}

\section{Vatra Dornei's tourism market attractiveness}

The first part of the survey, envisaged as an introduction for the theme announced in the first place to respondents, focused on the local tourism industry specific in the way it is perceived by its representatives and local tourism and/or environmental experts. Stakeholders were made aware of the fact that their statements would characterize an entire local level industry from the point of view of someone involved or observing tourism activities in the area. The questions about the forms of tourism offered by Vatra Dornei resort and their degree of attractiveness were important in order to define stakeholders' perspective on the tourism market and to reflect its dependency on climate resources and consequently its vulnerability to climate change.

In a first place, asked to give their opinion about the most representative forms of tourism offered by Vatra Dornei resort, respondents made a clear reference to spa tourism and winter sports (98\% respec- tively $91 \%$ ) and to mountaineering, especially in the warm season (87\%) (Figure 1).

Over half of respondents also mentioned agritourism and adventure sports as a component of Vatra Dornei tourism product whereas smaller percentages (about one third) of total answers referred to business and cultural tourism.

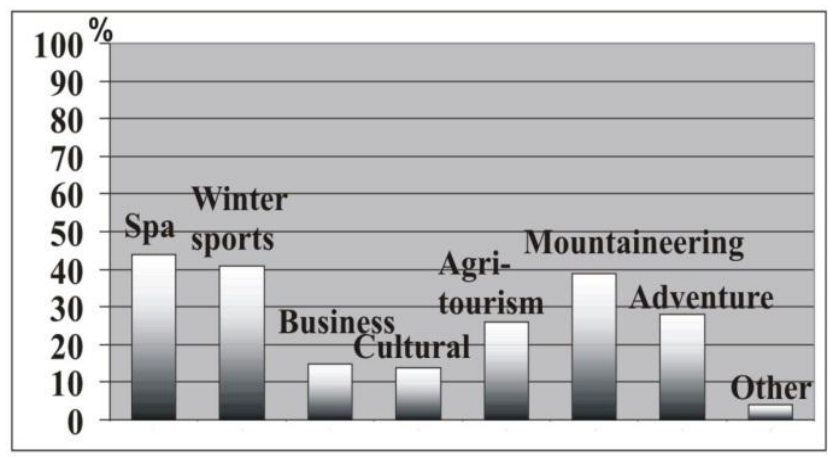

Figure 1. Stakeholders' options regarding the forms of tourism offered by Vatra Dornei resort (multiple choices were possible).

Asked to name the forms of tourism which generate the highest revenues at the resort level, the majority of respondents also mentioned in a first place spa tourism $(80 \%)$ and on a second place winter sports (75\%). In fact Vatra Dornei local development policy places on top of the private economic agents list three tourism societies. Answers to these first questions reflect the importance of climate resources in terms of attractiveness and cure factors for climate tourism as part of Vatra Dornei balneal-climate/spa product on the one hand and for outdoor mountaineering activities on the other hand. Respondents were also asked to distinguish among the attractiveness of different types of resources at the resort level.

In this way important shares of $54 \%$ respectively $38 \%$ of respondents appreciated mountaineering and fresh air during summer season as very attractive respectively pretty attractive. In terms of winter sports $70 \%$ of answers declared them pretty attractive and $24 \%$ very attractive, showing again a great importance of climate resource through this type of tourism, highly dependent on climate factor. However this segment lost in time part of its importance because of lack of investments in appropriate modern planning and extension of the ski domain. Important balanced shares of over $40 \%$ in the total number of answers declared spa resources very attractive respectively pretty attractive for Vatra Dornei resort.

The answers showed as in the case of winter sports, the fact that even if the local tourism market focuses to a great extent on spa tourism as a traditional product this form of tourism suffered a loss of interest and of demand because of lack of investments. Respondents reversed practically in the last set of answers the importance previously stated for the traditional spa and winter sports tourism. 
At the same time almost $70 \%$ of respondents agreed on the attractiveness of Bucovina's cultural resources, namely of UNESCO painted monasteries, for the local Vatra Dornei overall tourism product, declaring this type of resources pretty attractive even if previously only a third of them mentioned cultural tourism among tourism products offered by the resort. The stakeholders' opinion on local tourism market is completed through answers referring to Vatra Dornei general level of attractiveness for tourism demand compared to the one existing three decades ago in the '8os and to the degree of innovation for its tourism product (Figure 2).

Referring to these queries most part of respondents (approximately 67\%) considered that at present Vatra Dornei is attractive in a moderate way compared to its higher past attractiveness. Found in competition with regional tourism destinations oriented towards new and more attractive forms of tourism, Vatra Dornei tourist attractiveness was considered diminished to a small extent (11\%) or to a very high extent $(20 \%)$ by survey's respondents compared to its level in the '8os. These seem clear references to its traditional declining tourism industries whereas answers declaring a light increase $(43 \%)$ of local tourism attractiveness compared to the one in the communist period show that the resort didn't develop very much in the last years as a whole but tries to feel the gap by developing and offering new recreational segments (e.g. ecotourism and agri-tourism products).

These answers match with those about the innovation of Vatra Dornei tourism product (Figure 2). A balanced percentage of respondents, about one third of them, declared that the resort tourism offer is partially innovative $(36 \%)$, pretty innovative $(33 \%)$ or that it is not so innovative or not at all innovative (summed up percentage of $27 \%$ ). Most of those that declared Vatra Dornei tourism offer as being less attractive and not so innovative referred to inert old spa structures lacking financial resources and an appropriate investment and marketing strategy. Those considering that Vatra Dornei attractiveness increased in the last decades referred to the new built modern hotels and boarding houses and to providers oriented towards new active, green forms of tourism, mostly referring to outdoor nature and mountaineering activities. One should also state that approximately $50 \%$ respectively $30 \%$ of respondents declared extreme, adventure sports respectively horse riding as being innovative products of the resort, demonstrating in this way Vatra Dornei's orientation towards new recreational consumerism trends and its attempt to adapt regional competition.

\section{Stakeholders' perception on climate change / tourism interrelation}

The survey aimed at identifying in the first place stakeholders' perception on climate change as a global issue and on climate change impact on local tourism activities as an issue that already influences or will influence tourism activities in the future. The results showed that most of respondents already admit climate change effects on different socioeconomic sectors (population, health, life quality, human settlements) in general (36\% totally agreed) and are especially convinced about its impact in the future $(51 \%$ totally agreed). Asked to check examples of envisaged changes most part of stakeholders agreed about the increase of average yearly temperature $(78 \%)$ and the decrease of precipitations quantity during summer season (71\%). These high percentages match the most frequent climate anomalies underlined by scientific literature for mountain areas (Beniston, 2003).

Other climate change effects underlined by lower but still important percentages of respondents refer to the increase of temperature during different seasons as well as the change in the seasons' length $(64 \%$ - increase of temperature during summer season; $53 \%$ - increase of temperature during winter season; $58 \%$ shortening of winter season; $49 \%$ - increase in length

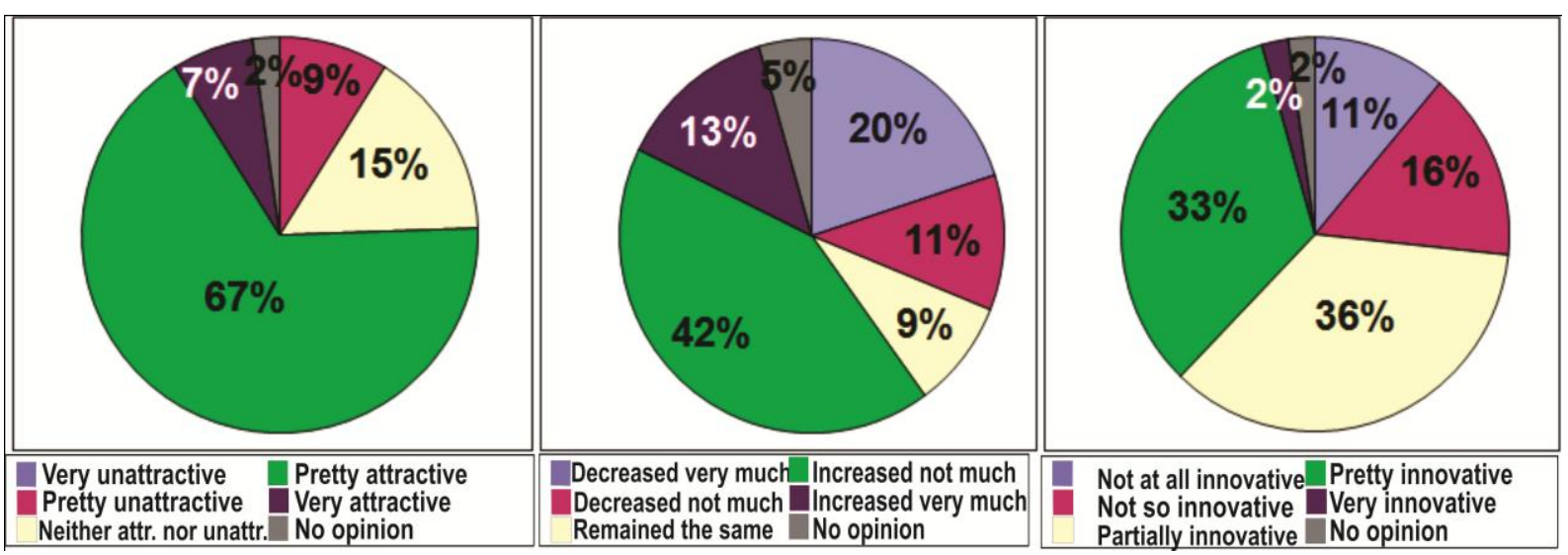

Figure 2. Respondents' answers regarding: a) the present degree of attractiveness of Vatra Dornei resort; b) the present degree of attractiveness of Vatra Dornei resort compared with the one in the late communist period (the '8os); c) the innovativeness of Vatra Dornei tourism offer. 


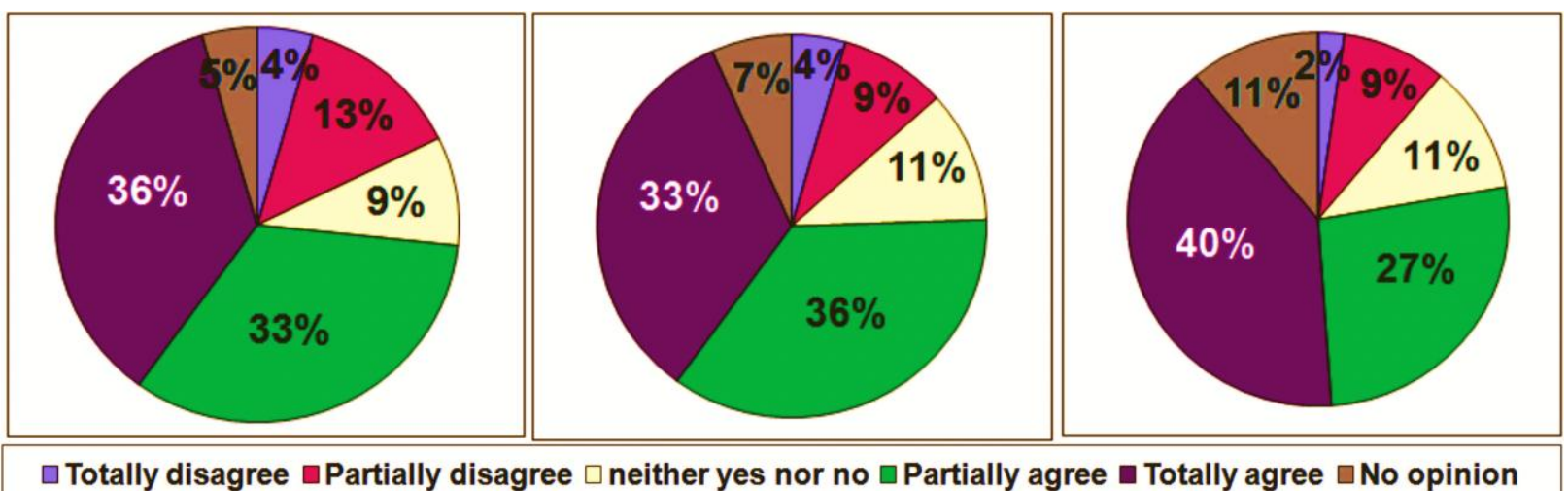

Figure 3. Respondents' answers regarding a) the fact that climate change represents a threat for tourism activities; b) the fact that climate change already causes problems for tourism activities in Vatra Dornei; c) the fact that climate change will cause problems for tourism activities in Vatra Dornei.

for summer season) and may as well be correlated with notifications stated by international researches and studies (Scott, McBoyle, Minogue \& Mills, 2006, CLAVIER, 2008).

However, apart from general public perception, local tourism and environmental experts perception upon climate change effects is clearly influenced by and reflects local conditions that determine in the end the success of their economic activities. This is also proved by responses referring to the growth of liquid precipitations during winter season and the appearance of thermal discomfort during the peak of summer season (July - August). Even if chosen by only one third of respondents, these last stated climate change effects, with an obvious more precise character, show stakeholders clear preoccupations for the matter and the fact that they noticed an environmental impact on their activities. Therefore most stakeholders totally and partially agreed on the fact that climate change represents at present a threat for tourism activities in general (Figure 3 ).

They also considered in a great proportion the topic to be relevant $(46 \%)$ and very relevant $(18 \%)$ for Vatra Dornei resort. However greater percentages of respondents were convinced that they will rather expect climate change to cause problems in future for tourism activities in Vatra Dornei (40\% totally agree) than those that admitted effects at present $33 \%$ totally agree) (Figure 3). For both present and future perspectives one should remark an impressive percentage of about $70 \%$ of respondents that were entirely and partially convinced that the phenomenon affects and/or will affect the tourism domain, thinking of both their own experiences and information they had about the issue.

In order to clearly emphasize the perception of climate change impact on tourism in Vatra Dornei resort, according to its tourism market specific as perceived by the stakeholders, questions were clearly divided in two sets: one referring to climate change impact during winter and the other during summer season. As shown in the figures 4 and 5 the survey results and thus local stakeholders are rather indicating a climate change impact on Vatra Dornei winter tourism than on its summer recreational activities.

Survey results show that $63 \%$ of respondents declared snow duration and thickness extremely important (relevant) for tourism activities in the resort. Over $75 \%$ of them totally agreed as well that the presence of snow is an essential condition for the beginning of winter tourism season and that its absence clearly influences in a negative way tourism demand and the occupancy rate for the entire resort. Asked if snow presence and its thickness influence the occupancy rate of their accommodation unit, stakeholders answered affirmatively also in a surprisingly high proportion, pointing a very high $(52 \%)$ and a high influence $(32 \%)$ as shown in Figure 4.

These figures, obtained only from the tourism representatives group of stakeholders answering our survey, reflect the fact that seasonality is very high for almost all accommodation units in Vatra Dornei resort. Depending more or less on the spa social demand voucher system, that foccused in the late years on the warm season months, hospitality units orient without exception towards complementary forms of tourism offered by the complex resort, such as winter sports during the cold season.

For summer season the answers were not so clearly divided in favor or against climate change issue and its effects. If in the case of winter sport industry direct negative effects are already felt as shown above, mountain summer tourism is to encounter rather positive effects of climate change through a possible extension of the summer season, so much wanted by a resort facing high seasonality and orienting towards outdoor sport activities or spa and airtherapy mixed health packages. Asked if temperature increase would be an essential condition for the extension of summer season length $27 \%$ of respondents declared that it is essential and about 30\% said that it is important but not essential (Figure 5). 


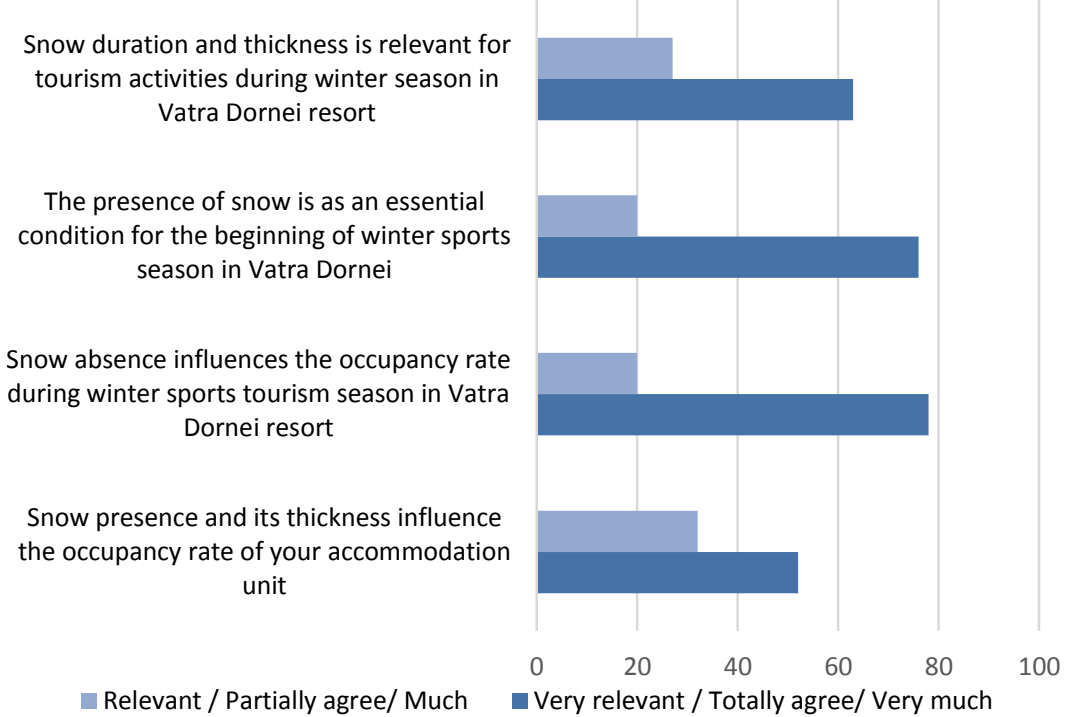

Figure 4. Respondents' answers regarding stated possible climate change effects for winter tourism season.

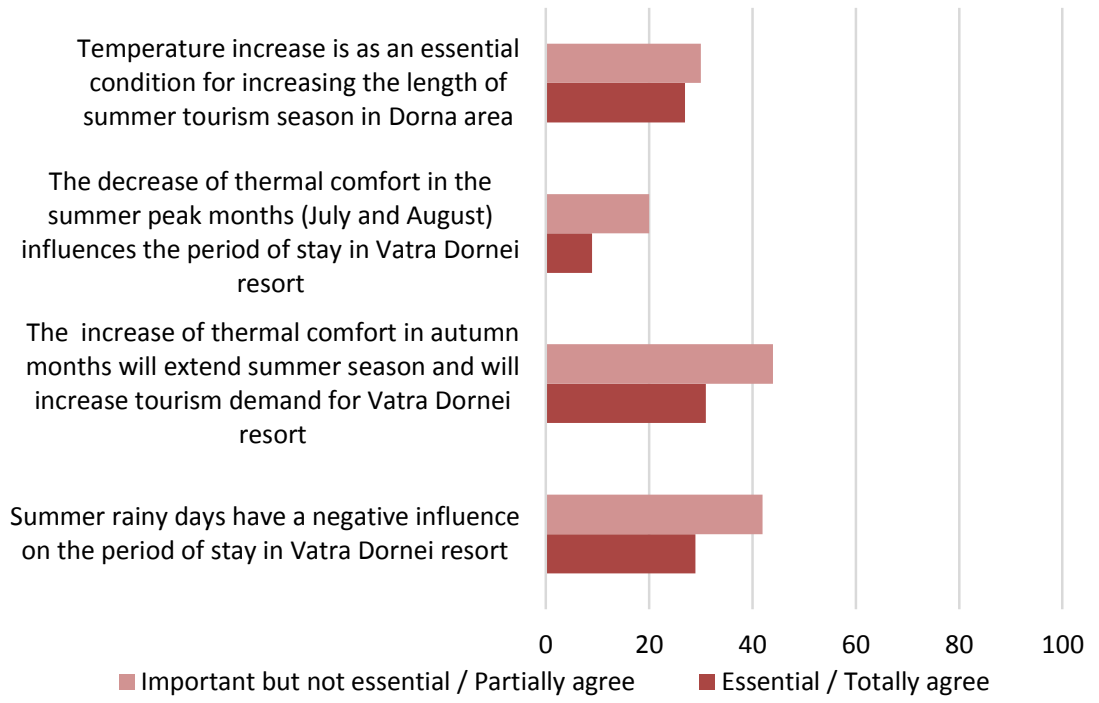

Figure 5. Respondents' answers regarding stated possible climate change effects for summer tourism season.

However one should consider Vatra Dornei geographical context as it represents a traditional mountain resort for which climate comfort was an essential make-up factor for tourism environment in the first place (Belén Gómez Martín, 2005) and for which, as in general, both negative and positive effects might occur (Surugiu, Breda, Surugiu, \& Dincă, 2011).

Located at $800 \mathrm{~m}$ altitude, in a mountain depression, this destination might thus experience positive changes from global warming through an extension of thermal comfort towards the end of summer season $(74 \%$ of respondents totally and partially agreed with this statement) rather than negative effects and discomfort in the peak summer season months, as it happens in other regions within the country. Home climate and destination choice (Eugenio-Martin \&
Campos-Soria, 2010) are already and might be closer interconnected variables in the case of Romanian domestic tourism oriented towards Vatra Dornei in the future.

In fact most stakeholders disregarded totally or partially the warming scenario $(40 \%)$ (Figure 5) or were neutral and had no opinion when asked about a possible thermal comfort decrease during peak summer months for their resort. They also remarked the fact that in a market already dominated almost entirely by domestic demand, coming especially from big plain and plateau cities located in the southern and eastern parts of the country, more severe climate change effects in tourists home settlements might be a pushing factor towards Romanian Carpathian destinations, therefore also towards Vatra Dornei resort. 
Stress coming from summer rainy days was also reflected by stakeholders' answers which totally agreed (29\%) and partially agreed (42\%) that it determines the length of stay in their resort during warm season.

A control question was further on asked demanding stakeholders to state if they observed changes in tourism demand (occupancy rate, length of stay, option to choose or reject their destination) because of climate change effects no matter the season and if they were mostly positive or negative. An interesting result might be considered the fact that over half of respondents $(60 \%)$ declared that they had noticed such changes. The shares were balanced between those observing negative and those mentioning positive changes. Clear references were made for the presence or absence of snow which had generated an increase respectively a decrease of tourism demand in the resort during cold season, reaffirming direct negative effects with important economic effects for winter sport industry in the resort. Stakeholders also referred to very hot summer periods in tourists regions of origins or to warm season rainy days in their resort with a contradictory effect of attraction respectively of rejection for tourism demand at the level of Vatra Dornei resort during peak summer months.

\section{Solutions - Information - Cooperation - Policies}

The relationship between tourism and climate change was clearly understood by most of stakeholders responding our survey in one way direction, depending on the degree in which climate is perceived as a major resource influencing this business sector. The issue is of particular interest for tourism actors in winter sports destinations and climate mountain resorts in general, as it is the case of Vatra Dornei tourism destination. Corporate responsibility (Frey \& George, 2010) for environmental reasons, either social or in our case ecological is rather a process than an achievement and is formed in time through appropriate and efficient educational, training and management programs at the enterprise level. Stakeholders interviewed in our case study expressed opinions regarding both the opportunities and the threats that global warming brings for tourism business.

Therefore about half of them partially and totally agreed that tourism business doesn't understand climate change implications. More than $40 \%$ of them disagreed with the fact that tourism industries in general contribute to global warming and didn't see any role for recreational activities in controlling this major problem. We may thus affirm the fact that for many small business owners, involved or not in a climate dependent industry, climate change is rather perceived through short term climate variability and the global phenomenon or scenarios are not very well understood and not important in view of current jobs they perform. Like any other publicly debated envi- ronmental problem with social implications, climate change remains an issue tackled at distance by tourism industry and is hardly approached by business and entrepreneurial system in general.

In this context we tried to define the level of information that stakeholders consider to have about the issue and their need to be informed, to cooperate or to be coordinated in order to reduce present or envisaged climate change effects on their business. In the first place, in order to make the transition towards this part of the survey, stakeholders were asked to characterize the capacity of tourism industry to adapt climate change in Vatra Dornei resort. Many of them appreciated that there is a low (38\%) and an average $(31 \%)$ capacity for tourism environment to adapt climate stressor (Figure 6).

As for the cooperation level among tourism organizations (information and/or education and training centers for tourism, tourism agencies) authorities (city halls, environment organizations) and local tourism investors, respondents declared in a high proportion that this is at a low level $(47 \%)$ or even that it is inexistent (16\%) (Figure 6).

Taking into consideration the lack of a cooperative environment most of respondents expressed the need of a central authority as coordinator, which should recommend actions and transmit accurate information on the topic, totally agreeing (27\%) and partially agreeing (33\%) with the fact that central tourism and/or administrative authorities should take the initiative over this issue. This issue outstands even more in the context in which a high proportion of responses $(49 \%)$ underlined the necessity to take measures in order to prevent the negative effects of climate change on tourism at the local level (Figure 7).

Even if important steps have been made in the last years in contouring Romanian policies to cope with the climate change issue, there has been little preoccupation to disseminate research results and recommendations in order to improve practically the adaptation capacity of economic stakeholders. From the obtained answers one may realize the fact that local industries are unaware of national policies not enough disseminated to the beneficiaries and however too far from their level of interest considered in terms of both territory and specificity of their activities. Therefore most of information stakeholders claim to have on the topic is received through media sources and internet. In fact about $58 \%$ of respondents declared that they have never been given information about climate change topic before, whereas most of those that declared themselves informed, mentioned as main sources internet and television. These answers underline stakeholders need to obtain accurate and trusted information and professional recommendations for this global problem with severe local implications they confront with. 


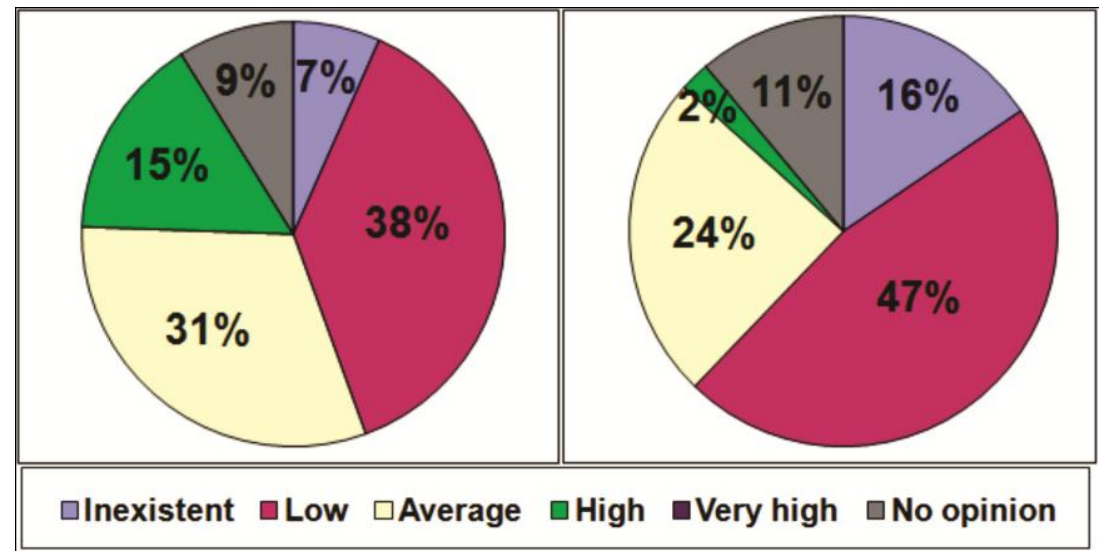

Figure 6. Respondents' answers regarding a) tourism capacity to adapt climate change in Vatra Dornei resort; b) the cooperation level among tourism organizations (info centers, tourism agencies), authorities and tourism investors at the local level.

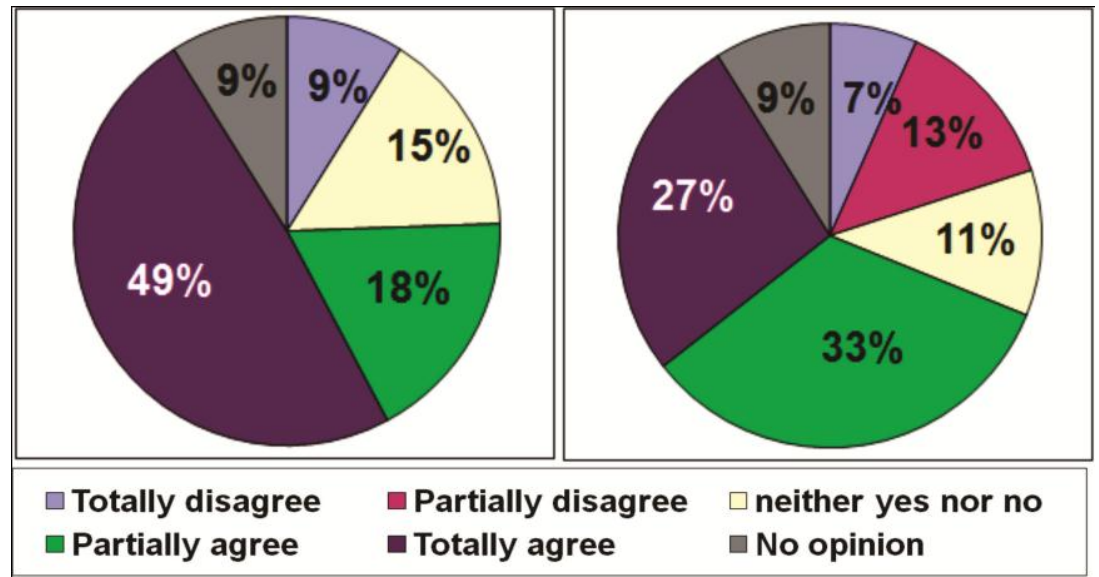

Figure 7. Respondents' answers regarding a) the fact that it is necessary to take measures in order to prevent the negative effects of climate change on tourism in Vatra Dornei resort; b) the fact that in order to evaluate and cope climate change issue central tourism and/or administrative authorities should take the initiative.

Actually more than $50 \%$ of the interviewed stakeholders estimated that there is not enough information available in order to elaborate an adequate strategy to adapt climate change and that both information and appropriate investments are missing so that industry should be able to face the problem. Local professionals' answers express once again the need of diversifying local tourism market and of modernizing it in order to better respond tourist demand standards and of being informed through trustable and coordinated means upon environmental factors that might affect economic efficiency.

In fact respondents were clearly unsatisfied about the influence that news on climate and weather topics have on tourism demand admitting in a high proportion $(76 \%)$ that it influences tourist behavior. One should thus deduce that news on meteorological phenomena or climate issues affected tourism activities and produced important economic effects at local level in the case of Vatra Dornei resort.
Asked to identify solutions for climate change problem at the resort level, stakeholders made clear references to their need to be correctly informed, coordinated and to cooperate so as to share the know-how of good practices on the matte and to take appropriate measures. This underlines the essential role of management and information for the potential of a socio-economic system to adapt in the local or regional context to environmental problems which may not be solved entirely on economic and technical solutions (Smit \& Wandel, 2006 in Trawoger, 2014, in press). In fact about half of respondents mentioned as solutions for handling climate change impact upon tourism industry the informing of local authorities and tourism investors regarding climate change impact on recreational activities (47\%), the promotion of research projects within this domain (53\%) and the dissemination of research results to general public $(44 \%)$ as well as the need to consult different categories of stakeholders involved in tourism activities about their point of view on the matter and on the 
most appropriated and recommended strategic measures to be taken $(67 \%)$. In fact stakeholders correctly perceived the fact that they should play an essential role in the design of local environmental policies in general and concerning their domain of interest in particular.

Another problem underlined in the solutions offered by stakeholders to increase the adaptive capacity of tourism industry to climate change effects, was the inertia of recreational activities in the resort. The lack of diversification and investments in infrastructure and leisure activities meant to attract and maintain tourism demand regardless of climate factor is to amplify thus in their opinion local environmental vulnerability in Vatra Dornei resort. Consequently among the most appropriate measures needed in order to increase local tourism adaptation capacity to climate change, respondents mentioned, in proportion of $93 \%$, the creation and development of new tourism attractions during summer season (e.g. ecotourism activities in Calimani National Park, horse riding, biking, adventure tourism, etc.).

A great percentage of them $(78 \%)$ also referred to the need to enforce innovation for traditional spa tourism activities and to develop an offer less dependent on climate resources with a new market vision oriented to clients' segmentation and diversification of health packages. A similar proportion of stakeholders $(78 \%)$ also referred to the necessity to develop tourism activities all the year round and especially of sport and active holidays which should be less dependent to climate and offer new demand attractive products at the same time.

Stakeholders have further been asked to mention solutions for tourism industry in case of clearly stated climate change problems as the snow absence and reduced possibilities of practicing winter sports in the cold season or the diminution of thermal comfort during July - August summer peak months. Beside seasonal solutions the answers referred for both summer and winter cases to previously mentioned solutions for improving tourism industry in general. For instance in case of an increased winter tourism vulnerability because of climate change effects artificial snow $(76 \%)$ or the extension of ski slopes at higher altitudes $(56 \%)$ were mentioned as well as the development of other forms of tourism (67\%).

The reorientation to other economic activities was mentioned as a solution by only $24 \%$ of respondents. Artificial snow and extension of ski slopes at higher altitudes are generally perceived and trusted, as many studies show, as a viable solution for the lack of snow in the future (Abegg, Agrawala, Crick, \& de Montfalcon, 2007; Wolfsegger, Gössling, \& Scott, 2008, Trawoger, 2014, in press). However the extension of ski domain, at least for Vatra Dornei area, would involve supplementary environmental problems and also a higher dependence on climate conditions of recreational industry. The answers of local stakeholders mentioned in this respect the diversification of local tourism products as the most feasible solution on a long term in general and for this resort in particular.

In the less probable case of thermal discomfort during summer, stakeholders mentioned as solutions, the focus of tourism industry on spa rather at the beginning and the end of summer season (June, September) $(73 \%)$ and the development of other forms of leisure products $(69 \%)$ to counterpart the monopoly owned by traditional health tourism. One may also remark in this context an enforced seasonality induced by social spa tourism in Vatra Dornei resort which concentrates as well as other products (e.g. mountaineering, active holidays) during summer months. There is an obvious need in terms of competitiveness and economic efficiency, as expressed by survey answers, to push social tourism towards the ends of summer season. This measure will enhance the profitability of tourism industry and satisfy as well different types of social tourism demand with different financial and time budgets (e.g. retired people, families etc.).

In order to make us place the climate - tourism connection into a larger context and to further understand the economic and tourism domain transformations that have occurred in the late years independent to it a last questions of the present survey asked stakeholders to freely mention positive and negative aspects that appeared in their activity/were observed for local tourism industry in the late years in Vatra Dornei resort. A first aspect would be that negative aspects prevail to positive ones. Among them environmental issues linked to tourism domain occupy an important place. Numerous references mentioned deforestation, traffic noise, pollution, degradation of infrastructure and lack of investments as important actual problems with a high impact on tourism activities. Other answers outlined domestic demand problems generated by prices increase and the reduction of power of purchase and travel budget as it concentrates $80-90 \%$ of those opting for spa services in Vatra Dornei resort. Tourism negative behavior causing litter, traffic congestion, noise, etc. was also mentioned.

Among positive aspects occurred in the evolution of Vatra Dornei tourism activities stakeholders mentioned an important recent development of accommodation units, an implicit increase of labor force in tourism sector as well as some punctual projects for tourism sport infrastructure development (e.g. Parc ski track and the modernization of Negresti ski track). One negative aspect signaled by stakeholders' answers was the unsatisfactory conditions for tourists' amusement and sport practice needs of the present ski domain in Vatra Dornei. This traditional tourism destination meets already an important 
competition from recent developed or extended regional resorts (Gura Humorului or Borșa) and struggles to maintain itself attractive for present tourism demand. Climate change issue comes in this context as a supplementary variable, raising numerous question marks and jeopardizing future tourism investments. Consequently one should say that tourism stakeholders show a real interest for this topic at the level of Vatra Dornei resort, expressing their need to be accurately informed, coordinated and involved in the planning of an efficient integrative management strategy in order to manage appropriately this problem at the local level.

This is to be stated in the context in which local development policies and tourism sector strategies should be adapted to industry needs and requirements on the one hand and to reflect European and national policies on the other hand. Vatra Dornei benefits currently of an old Agenda 21 local development strategy which states among its main objectives regarding tourism sector the modernization and extension of the present ski domain regardless to sector vulnerabilities signaled by national and European projects, strategies and legislation.

Under the influence of the European legislative context the National Strategy on Climate Change of Romania 2005-2007, accompanied by a National Action Plan were designed, approved through the Governmental Decision no 645/2005 and no 1877/2005 respectively. The strategy has been reformulated later on for the 2009 - 2012 period and currently for the 2013 - 2020 period. Another document which should be mentioned is the national Guide on the adaptation to the climate change effects, approved by Ministerial Order no $1170 / 2008$ which included as well as the above mentioned policies a chapter on tourism.

Despite general policies preoccupations for the subject of economic impact and adaptation to climate change phenomenon there is little progress for contouring local policies containing practical aspects and guides of good practices for different domains including tourism. All these in an international context preoccupied more and more to increase 'stakeholder participation in environmental decision-making' (Reed, 2008).

A clear aspect which appears for our study case would be thus that climate change issue should be approached at local level within the general national policy frame. Moreover Vatra Dornei should make an integrative complex separate tourism strategy and define climate change vulnerability differently from a group of stakeholders to another, clearly establishing responsible authorities and appropriate means to reduce its possible future negative impact. Disposing of an old local Agenda 21 development strategy and facing competition from regional destinations while being stuck in a traditional tourism market, still dependent on an inert social voucher system, Vatra
Dornei clearly emphasizes an economic vulnerability outlined by survey answers. Climate could be thus perceived as a supplementary stressor inducing sensitivity for different leisure segments in a transforming already vulnerable tourism market.

\section{Conclusions}

Located in the northern part of Romanian Carpathians, Vatra Dornei represents one of the few resorts of national interest with complex profile in Romania. Focusing both on mountain recreational activities with its summer and winter sports component and on spa (balneal and climate) tourism the destination depends consequently to a great extent on climate resources which show a clear variability of main parameters and elements on which outdoor recreational activities are based. Beside statistic and modeling evidences of climate and tourism data, the opinions of stakeholders involved or observing the local tourism industry, are of great importance. They are an essential element if regarding the difficulty of shaping an accurate connection climate - tourism, already recognized by the scientific literature (CLAVIER, 2008) but also for contouring possible economic adapting strategies to evolving environmental exposure.

Climate change effects are to be felt in different degrees by various stakeholder groups involved in tourism industry at the local level, depending on their profile and thus on their dependency on climate resources as well as on their individual adaptive capacity on the background of a coordinated resort strategy to reduce sector internal vulnerability and environmental exposure. In this context the present study attempted to emphasize local stakeholders' point of view on the felt climate change impact and possibilities of tourism industry to adapt to it in a representative Romanian mountain spa resort.

The applied survey emphasized a great dependency of Vatra Dornei tourism on natural resources and an important exposure to climate change effects as air-therapy activities, outdoor mountaineering or winter sports tourism, forming the core of its tourism offer, present an important vulnerability to climate change effects. Consequently most of stakeholders declared that climate change is already felt by tourism activities in Vatra Dornei, both negatively through the reducing of snow duration and quantity which endanger winter sports activities and positively through the extension of summer tourism season towards autumn months once with the increase in thermal comfort.

Stakeholders also declared a low adaptation capacity for Vatra Dornei to climate change impact as it lacks information and a cooperation culture. Consequently stakeholders agreed on the necessity to take 
measures to cope with climate change problem, among which they mentioned the development of entertainment industry, of tourism forms less dependent on climate resources, the dissemination of research results on the topic, coordinated policies and accurate information and education for different territorial levels. It was underlined in this way the necessity to form the understanding capacity on the issue for different tourism stakeholder groups, which should be informed and trained in order to plan their business considering the climate exposure factor. The development of efficient communication skills and an effective cooperation and involvement of central and local authorities, scientific experts, tourism industry representatives, tourists and inhabitants would be essential in order to develop a functional strategy and to increase stakeholders' capacity to adapt evolving climate factors both in general and for Vatra Dornei resort in particular.

\section{Acknowledgements}

This paper was supported by CNCSIS-UEFISCU, project number NP II-HR 94/2010, Contract no. 30/28.07.2010 and the Sectoral Operational Programme Human Resources Development (SOP HRD), financed from the European Social Fund and by the Romanian Government under the contract number SOP HRD/89.

\section{References}

Abegg, B 1996, Klimaänderung und Tourismus. Klimafolgenforschung am Beispiel des Wintertourismus in den Schweizer Alpen, Switzerland: vdf, Zurich.

Abegg, B \& Froesch, R 1994, 'Climate change and winter tourism, Impact on transport companies in the Swiss canton of Graubünden', in M Beniston (ed.) Mountain Environments in Changing Climates, Routledge, London, pp. 328-348.

Abegg, B, Agrawala, S, Crick, F \& de Montfalcon, A 2007, 'Climate change impacts and adaptation in winter tourism' in S Agrawala (ed.) Climate change in the European Alps, OECD Publishing, Paris, pp. 25-6o.

Becken, S 2013, 'A review of tourism and climate change as an evolving knowledge domain', Tourism Management Perspectives, vol. 6, pp. 53-62.

Belén Gómez Martín, M 2005, 'Weather, Climate and Tourism A geographical Perspective', Annals of Tourism Research, vol. 57(3), pp. 571-591.

Belle, N \& Bramwell, B 2005, 'Climate change and small island tourism: policy maker and industry perspectives in Barbados', Journal of Travel Research, vol. 44, no. 1, pp. 3241.

Beniston, M 2003, 'Climatic change in mountain regions: a review of possible impacts', Climatic Change, no. 59, pp.
5-31.

Bicknell, S \& McManus, P 2006, 'The canary in the coalmine: Australian ski resorts and their response to climate change', Geographical Research, vol. 44, no. 4, pp. 386-400.

Bigano A \& Bosello F 2007, Impacts of climate change on tourism in the Italian Alps: An economic assessment, Report for the Climalp Project.

Breiling, M 1993a, Die zukuenftige Umwelt - und Wirtschaftssituation peripherer alpiner Gebiete, $\mathrm{PhD}$ thesis, Universitaet fuer Bodenkultur, Vienna,

Breiling, M 1993b, 'Klimaaenderung, Wintertourismus und Umwelt' in W Pillmann \& A Wolzt (eds.) Umweltschutz im Tourismus - Vom Umdenken zum Umsetzen, pp. 3341.

Breiling, M \& Charamza, P 1999, 'The impact of global warming on winter tourism and skiing: a regionalised model for Austrian snow conditions', Regional Environmental Change, vol. 1, no. 1, pp. 4-14.

Bultot, F, Gellens D, Spreafisco, B \& Schedler, B 1994, 'Effects of climate change on snow accumulation and melting in the Broye catchement (Switzerland)', Climatic Change, vol. 28, pp. 339-363.

Burki, R 2002, 'Climate change as a threat to tourism in the Alps', Climate Research, vol. 20, pp. 253-257.

Bürki, R, Elsasser, H \& Abegg, B 2003, 'Climate Change Impacts on the Tourism Industry in Mountain Areas', ist International Conference on Climate Change and Tourism, Djerba, 9-11 April 2003.

Bürki, R, Elsasser, H, Abegg, B \& Koenig, U 2005, 'Climate change and tourism in the Swiss Alps', in CM Hall \& J Higham (eds) Tourism, recreation and climate change, Clevedon: Channel View, pp. 155-163.

Butler, RW 1980, 'The concept of a tourist area cycle of evolution: Implications for management of resources', Canadian Geographer, vol. 24, no. 1, pp. 5-12.

Buzinde, CN, Manuel-Navarrete, D, Kerstetter, D \& Redclift, M 2010, 'Representations and adaptation to climate change', Annals of Tourism Research, vol. 57, no. 5, pp. 581-605.

Charara, N, Cashman, A, Bonnell, R, \& Gehr, R 2011, 'Water use efficiency in the hotel sector of Barbados', Journal of Sustainable Tourism, vol. 19, no. 2, pp. 231-245.

Cheval, S(ed.) 2003, Indici şi metode cantitative utilizate în climatologie, Ed. Universităţii din Oradea.

Ciangă, N 1998, Turismul în Carpaţii Orientali. Studiu de geografie umană, Presa Universitară Clujeană, ClujNapoca.

CLAVIER, 2008, TOURROM Final Rapport - Winter tourism in Prahova Valley - Poiana Braşov Area, An assessment of sectoral vulnerability to climate change on case study level.

Dawson, J \& Scott, D 2013, 'Managing for climate change in the alpine ski sector', Tourism Management, vol. 35, pp. 244-254.

Dickinson, J 2010, 'Tourism and climate change - An introduction', Journal of Transport Geography, vol. 18, pp. 445 446. 
Dincă, AI, Surugiu, C \& Micu, D 2009, 'Stakeholder's perception on the influence exerted by the variability of the winter climatic conditions on the tourism activities within the Prahova Valley - Poiana Braşov mountain area', Analele Universității din Craiova, Seria Geografie, serie nouă, vol. 12, pp. 201-210.

Dincă, AI 2013, Turismul durabil în Culoarul transcarpatic Gura Humorului - Câmpulung - Vatra Dornei - Bârgău, Editura Universităţii din București.

Dingeldey, A \& Soboll, A 2010, The Impact of Climate Change on Alpine Leisure Tourism in Germany and Austria, BEST EN Think Tank X, Networking for Sustainable Tourism.

Duchosal, E 2007, Climate change impacts and adaptation to winter tourism. How adapting winter tourism to climate change?", Based on a survey realised in the northern French Alps, Master of Arts in European Tourism Management, Bournemouth University (UK).

Erdeli, G, Dincă, AI, Gheorghilaş, A \& Surugiu, C 2011, 'Romanian Spa Tourism: a Communist Paradigm in a Post Communist Era', Human Geographies, Journal of Studies and Research in Human Geography, vol. 5, no. 2, pp. 41-56.

Eugenio-Martin JL \& Campos-Soria, JA 2010, 'Climate in the region of origin and destination choice in outbound tourism demand', Tourism Management, vol. 31, pp. 744-753.

Frey, N \& George, R 2010, 'Responsible tourism management: The missing link between bussines owners' attitudes and behaviour in the Cape Town tourism industry', Tourism Management, vol. 31, pp. 621-628.

Ge, Q, Dai, J, Liu, J, Zhong, S \& Liu, H 2013, 'The effect of climate change on the fall foliage vacation in China', Tourism Management, vol. 38, pp. 8o-84.

Hein, L, Metzger, MJ \& Moreno, A 2009, 'Potential impacts of climate change on tourism; a case study for Spain', Current Opinion in Environmental Sustainability, vol. 1, pp. 170-178.

Hoffmann, VH, Sprengel, DC, Ziegler, A, Kolb, M \& Abegg, B 2009, 'Determinants of corporate adaptation to climate change in winter tourism: An econometric analysis', Global Environmental Change, vol. 19, pp. 256-264.

IPCC 2007, Climate Change 2007: Synthesis Report, An Assessment of the Intergovernmental Panel on Climate Change.

Jennings, S 2004, 'Coastal Tourism and Shoreline Management', Annals of Tourism Research, vol. 57, no. 5, pp. 581605 .

Jones, AL \& Phillips, MR (eds.) 2011, Diasappearing Destinations: Climate Change and Future Challenges for Coastal Tourism, CABI Publishing.

Klint, LM, Jiang, M, Law, A, De Lacy, T, Filep, S, Calgaro, E, Dominey-Howes, D \& Harrison, D 2012, 'Dive Tourism in Luganville, Vanuatu: Shocks, Stressors, and Vulnerability to Climate Change', Tourism in Marine Environments, vol. 8, no. 1-2, pp. 91-109.

Koenig, U 1994, 'Entwicklung und Zukunft des Gletscherskitourismus in der Schweiz', in H Elsasser (ed.) Wirtschaftsgeographie und Raumplanung, vol.19, Department of Geography, University of Zurich.
Koch, E \& Rudel, E 1990, 'Moegliche Auswirkungen eines vers tärkten Treibhauseffekts auf die Schneeverhältnisse in Oesterreich', Sonderdruck aus Wetter und Leben, vol. 42, no. 3/4, pp. 137-153.

Koenig, U \& Abegg, B 1997, 'Impacts of Climate Change on Winter Tourism in the Swiss Alps', Journal of Sustainable Tourism, vol. 5, no. 1.

Kontogianni, A, Skourtos, SM, Langford, HI, Bateman, JI \& Georgiou, S 2001, 'Integrating stakeholder analysis in nonmarket valuation of environmental assets', Ecological Economics, vol. 37, no. 1, pp. 123-138.

Meier, R 1998, Soziooekonomische Aspekte von

Klimaaenderungen und Naturkatastrophen in der Schweiz, Schlussbericht NFP 31. vdf, Zuerich.

Micu, D \& Dincă, AI 2008, 'Climate Variability and its Implications for Winter Mountain Tourism in the Prahova Valley - Poiana Braşov Area', Proceedings PEEC 2008, vol. I, Supplement of "Quality-access to success" Journal, vol. 94, pp. 232-241.

Moen, J \& Fredman, P 2007, 'Effects of climate change on Alpine skiing in Sweden', Journal of Sustainable Tourism, vol. 15, pp. 418-437.

Mohnl, V 1996, The fluctuation of winter-sport-related snow parameters of the last fifty years in the Austrian Alps, Wetter und Leben, 48.

Nicholls, S \& Holecek, D 2008, 'Engaging stakeholders in the development of climate change decision-support tools: A case study from Michigan, USA', Tourism Review International, vol. 12, pp. 25-42.

Peric J, Jurdana, DS \& Grdic ZS 2013, 'Croatian tourism sector's adjustment to climate change', Tourism Management Perspectives, vol. 6, pp. 23-27.

Phillips, MR \& Jones, AL 2006, 'Erosion and Tourism Infrastructure in the Coastal Zone: Problems, Consequences and Management', Tourism Management, vol. 27, no. 3, pp. 570-579.

Pickering, C 2011, 'Changes in demand for tourism with climate change: a case study of visitation patterns to six ski resorts in Australia', Journal of Sustainable Tourism, vol. 19, no. 6, pp. 767-781.

Pongkijvorasin, S \& Chotiyaputta, V 2013, 'Climate Change and tourism: impacts and responses. A case study of Khaoyai National Park', Tourism Management Perspectives, vol. 5, pp. 10-17.

Reed, SM 2008, 'Stakeholder participation for environmental management: A literature review', Biological Conservation, vol. 141, no. 10, pp. 2417-2431.

Rotariu, T (coord.), Bădescu, G, Culic, I, Mezei, E, Mureșan, C 2006, Metode statistice aplicate în ştiințele sociale, Polirom, Iaşi.

Scott, D, McBoyle, G, Mills, B \& Minogue, A 2004, 'Climate change and the ski industry in Eastern North America: A reassessment' in A Matzarakis, C Freitas, D Scott (eds.) Advances in Tourism Climatology, Berichte des Meteorologischen Institutes der Universität, Freiburg, pp. 90-96.

Scott, D, McBoyle, G, Minogue, A \& Mills, B 2006, 'Climate Change and the sustainability of ski-based tourism in 
Eastern North America: A reassessment', Journal of Sustainable Tourism, vol. 14, no. 4, pp. 376-398.

Scott, D, Jones, B \& Konopek, J 2007, 'Implications of climate and environmental change for nature-based tourism in the Canadian Rocky Mountains: A case study of Waterton Lakes National Park', Tourism Management, vol. 28, pp. 570-579.

Scott, D, Hall, C M, Gössling, S 2012, Tourism and Climate Change: Impacts, Adaptation and Mitigation, Routledge.

Sebek, O 1990, 'Impacts of climatic change in the Czech Republic in the first half of the 21st century' in R Bràzdil (ed.) Climatic Change in the Historical and Instrumental Periods, Masaryk University, Brno, pp. 119-124.

Smit, B \& Wandel, J 2006, 'Adaptation, adaptive capacity and vulnerability', Global Environmental Change, vol. 16, no. 3, pp. 282-292.

Stern, $N$ 2006, Stern Review: The Economics of Climate Change. HM Treasury, London.

Surugiu, C, Dincă, AI \& Micu, D 2010, 'Tourism Destinations Vulnerable to Climate Changes: An Econometric Approach on Predeal Resort', Buletinul Universităţii Petrol - Gaze din Ploieşti, Seria Ştiințe Economice, vol. 62, no. 1, pp. 111-120.

Surugiu, C, Breda, Z, Surugiu, MR \& Dincă, AI 2011, 'Climate change impact on seaside tourism. Portugal and Romania: two different case studies with strong particularities', Revista Economică, Sibiu, vol.1, no. 54, pp. 113-135.

Surugiu, C, Frenţ, C, Surugiu, MR \& Dincă, AI 2012, Analiza și evaluarea vulnerabilității și capacității de adaptare la schimbările climatice în sectorul turistic, Studiu de caz privind staţiunile Predeal, Eforie Nord și Vatra Dornei, Editura Universitară, București.

Tepfenhart, M, Mauser, W \& Siebel, F 2007, 'The Impacts of Climate Change on Ski Resorts and Tourist Traffic', in A Matzarakis, CR de Freitas, D Scott (eds.) Developments in Tourism Climatology, Commission Climate, Tourism and Recreation, International Society of Biometeorology.
Tervo, K 2007, 'Weather and Climate as Limiting Factors in Winter Tourism in Polar Areas: Changing Climate and Nature-Based Tourism in Northern Finland', in A Matzarakis, CR de Freitas, D Scott (eds.) Developments in Tourism Climatology, Commission Climate, Tourism and Recreation, International Society of Biometeorology.

Trawoger, L 2014 (in press), 'Convinced, ambivalent or annoyed: Tyrolean ski tourism stakeholders and their perceptions of climate change', Tourism Management, vol. 40, pp. 338-351.

Turton, S, Dickson, T, Hadwen, W, Jorgensen, B, Pham, T, Simmons, D, Tremblay, P \& Wilson, R 2010, 'Developing an approach for tourism climate change assessment: Evidence from four contrasting Australian case studies', Journal of Sustainable Tourism, vol. 18, no. 3, pp. 429-448. UNWTO 2007, Davos Declaration, Climate Change and Tourism: Responding to Global Challenges, Second International Conference on Climate Change and Tourism, 3 October 2007, Davos, Switzerland.

UNWTO 2009, From Davos to Copenhagen and Beyond: Advancing Tourism's Response to Climate Change, UNWTO Background Paper.

Vrtačnik Garbas, K 2007, 'The Potential Influences of Climate Changes on Tourist Demand in Winter Sport Centres in Slovenia”, in A Matzarakis, CR de Freitas, D Scott (eds.) Developments in Tourism Climatology, Commission Climate, Tourism and Recreation, International Society of Biometeorology.

Wolfsegger, C, Gössling, S \& Scott, D 2008, 'Climate change risk appraisal in the Austrian ski industry', Tourism Review International, vol. 12, no. 1, pp. 13-23.

Wong, E, De Lacy, T \& Jiang, M 2012, 'Climate change adaptation in tourism in the South Pacific - Potential contribution of public-private partnerships', Tourism Management Perspectives, vol. 4, pp. 136-144. 